\title{
Combination of platelet count and mean platelet volume (COP-MPV) predicts postoperative prognosis in both resectable early and advanced stage esophageal squamous cell cancer patients
}

\author{
Fan Zhang ${ }^{1} \cdot$ Zhaoli Chen $^{1} \cdot$ Pan Wang $^{1} \cdot$ Xueda $\mathrm{Hu}^{1} \cdot$ Yibo Gao ${ }^{1} \cdot \mathrm{Jie} \mathrm{He}^{1}$
}

Received: 4 November 2015 / Accepted: 29 December 2015 / Published online: 16 January 2016

(C) The Author(s) 2016. This article is published with open access at Springerlink.com

\begin{abstract}
The aim of this study is to search the most powerful prognostic factor from routine blood test for esophageal squamous cell cancer (ESCC) patients. Multiple laboratory tests were evaluated including those reflecting red blood cell parameters (hemoglobin $(\mathrm{Hb})$, mean corpuscular volume (MCV), mean corpuscular hemoglobin concentration $(\mathrm{MCHC})$, and red blood cell distribution width (RDW)), platelet morphological parameters (mean platelet volume (MPV) and platelet count (PLT)), blood coagulation status (D-dimer), and tumor biomarker (CA19-9). Known inflammatory indices (NLR and PLR) were also calculated. A total of 468 patients who were diagnosed with ESCC between December 2005 and December 2008 were retrospectively analyzed in this study. By utilizing univariate and multivariate Cox proportional hazard analyses, we found that PLT and MPV were significantly associated with overall survival (OS) and disease-free survival (DFS) of ESCC patients, with optimal cutoff values of 212 and 10.6, respectively. Moreover, the combination of the preoperative PLT and MPV (COP-MPV) was calculated as follows: patients with both PLT $\left(\geq 212 \times 10^{9} \mathrm{~L}^{-1}\right)$ and MPV $(\geq 10.6 \mathrm{fL})$ elevation were assigned a score of 2 , and patients with one or neither were assigned a score of 1 and 0 . The COP-MPV was an independent prognostic factor for OS (hazard ratio (HR) $0.378,95 \%$ confidence interval (CI) 0.241 to $0.593, P<0.001,0 / 2)$ and DFS (HR $0.341,95 \%$ CI 0.218 to $0.534, P<0.001,0 / 2)$ in multivariate analyses. In subgroup analyses for early (stages I and II) and locally (stage III)
\end{abstract}

Jie He

prof.hejie@263.net

1 National Cancer Center, Cancer Hospital and Institute, Chinese Academy of Medical Sciences, Panjiayuannanli 17, Chaoyang District, Beijing 100021, China advanced stage patients, COP-MPV was found significantly associated with OS and DFS in each group $(P=0.025$ and $P=0.018$ for OS and $P=0.029$ and $P=0.002$ for DFS). In conclusion, we considered that COP-MPV is a promising predictor for postoperative survival in ESCC patients.

Keywords Esophageal squamous cell cancer · Mean platelet volume $\cdot$ Platelet count $\cdot$ Scoring system $\cdot$ Prognosis

\section{Introduction}

Among the most lethal malignancies, esophageal cancer (EC) ranks the sixth worldwide, leading to approximately 400,000 deaths in 2012 [1]. In China, esophageal cancer is the fourth leading cause of all cancer deaths, representing a major problem of public health in some high-risk rural areas [2]. The dominant histopathological type of EC is squamous cell carcinoma (ESCC) in Chinese patients, which covers $90 \%$ of all cases [3]. Despite the progress in radical resection and adjuvant therapy (radiation and chemotherapy), ESCC still shows a poor 5 -year survival rate of less than $30 \%$ [4]. The tumor node metastasis (TNM) staging, especially the status of lymph node metastasis, is currently the best predictor for ESCC patient survival [5]. Although several studies had identified certain survivalrelated biomarkers [6-8], they were less powerful and hardly able to be converted to clinical use. Thus, it is important to recognize effective and easy-obtained biomarkers for ESCC prognosis.

In the past decade, platelet activation has been demonstrated as a crucial biological process in carcinogenesis and metastasis [9-11]. Platelet count (PLT) and mean platelet volume (MPV) are two main characteristics to evaluate platelet activation [12]. Patients with thrombocytosis have been reported to have worse prognosis in multiple solid tumors, such as ovarian cancer [13], endometrial cancer [14], gastric cancer 
[15], and colorectal cancer [16]. On the other hand, high MPV reflected an abnormal rate of platelet production and stimulation [17]. Recent studies revealed that MPV levels were relatively higher in tumor patients than in normal controls and associated with poor prognosis in some gastrointestinal neoplasms [18-20]. However, the predictive value of PLT combined with MPV for postsurgery survival in ESCC has not been yet investigated.

In this study, we assessed and checked the prognostic value of preoperative PLT and MPV in 468 ESCC patients. Moreover, we took the utility of a novel prognostic system based on platelet activation, termed combination of platelet count and MPV (COP-MPV), which made a promising distinction between better and worse prognosis in both subgroups of early (stages I and II) and locally advanced stage (stage III) ESCC patients.

\section{Materials and methods}

\section{Patients}

Patients with histopathologically confirmed ESCC with no distal metastasis (TNM stage I-III) were enrolled in the study from December 2005 to December 2008. All patients underwent esophagectomy at the Cancer Institute and Hospital, Chinese Academy of Medical Sciences (CAMS), with written informed consent. The exclusion criteria were (1) severe complications or deaths occurred within 30 days after surgery, (2) preoperative systemic inflammatory response syndrome (SIRS), (3) neoadjuvant radiotherapy or chemotherapy, and (4) evidence of infection or autoimmune disease. All patients underwent a careful preoperative evaluation, including clinical history taking, physical examination, laboratory blood testing (biochemistry, complete blood cell counts, coagulation status, and serum tumor marker), pulmonary function test, and multiple radiography (computed tomography (CT) or magnetic resonance imaging (MRI)). Clinicopathological information of the patients were obtained from the medical records, including age, gender, smoking history, drinking status, tumor location, differentiation grade, maximum tumor diameter, lymph node metastasis, TNM stage, and history of adjuvant chemotherapy and radiotherapy. The TNM stage was assessed according to American Joint Committee on Cancer (AJCC) staging manual (seventh edition) [21]. Patients underwent adjuvant radio/chemotherapy after surgery according to TNM stages and family economic status. The laboratory characteristics, including hemoglobin $(\mathrm{Hb})$, mean corpuscular volume (MCV), mean corpuscular hemoglobin concentration (MCHC), red blood cell distribution width (RDW), mean platelet volume (MPV), platelet count (PLT), D-dimer, and CA19-9, were performed within 5 days prior to surgery. The last follow-up date was July 9, 2015. This study was approved by the medical ethics committee of the Cancer Institute and Hospital, CAMS.

\section{Statistical analysis}

Overall survival (OS) was defined as follows: the time from surgery to the time of patients' death for any cause or the last follow-up date when the patient was known alive. Diseasefree survival (DFS) was calculated from the date of operation to first tumor recurrence. Neutrophil-lymphocyte ratio (NLR)/ platelet-lymphocyte ratio (PLR) was, respectively, defined as absolute neutrophil/lymphocyte count divided by absolute lymphocyte count. Categorical variables were shown as frequency (percentage), while continuous variables were presented as the mean values \pm standard deviation. Unpaired $t$ or $\chi^{2}$ test was used to compare whether statistical differences between groups were significant. The optimal cutoff values of all continuous variables were determined by receiver operating characteristic (ROC) curve. We used univariate analysis to narrow down the list of possible prognostic factors. Variables with $P$ value $<0.1$ in univariate analysis were brought into multivariate Cox proportional hazard model to determine their independency. Specifically, the cutoff values of PLT and MPV were $212\left(\times 10^{9} \mathrm{~L}^{-1}\right)$ and 10.6 (fL), respectively. The COP-MPV score was calculated on the basis of these two platelet characteristics. Patients with both a higher platelet count $\left(\geq 212 \times 10^{9} \mathrm{~L}^{-1}\right)$ level and a higher mean platelet volume ( $\geq 10.6 \mathrm{fL})$ level were grouped a score of 2 , and patients with one or neither were grouped a score of 1 and 0 , respectively. Kaplan-Meier curves and log-rank test were used to compare survival differences among groups. All statistical analyses were conducted by SPSS 21.0 software (IBM Corporation, Somers, NY, USA). $P<0.05$ was considered statistically significant.

\section{Results}

A total of 468 patients were enrolled in this study, including 376 men and 92 women. The mean age of all patients was $59.5 \pm 9.0$ years (median age 60 years; range 36 to 81 ). Mean follow-up period was $49.1 \pm 32.6$ months (range 3.2 to 114.5 months). Two-hundred seventy (57.7\%) patients had died during the observation period. The 5-year overall survival rate was $45.0 \%$ for the whole cohort. The distribution of TNM stages was stage I, 46 (9.8\%); stage II, 199 (42.6\%); and stage III, 223 (47.6\%). Mean PLT and MPV were 218 $\pm 65 \times 10^{9} \mathrm{~L}^{-1}$ (range 52 to 611 ) and $10.6 \pm 1.1 \mathrm{fL}$ (range 7.1 to 14.4), respectively. Mean (SD, range) levels of other selected laboratory variables or ratios were as follows: $\mathrm{Hb}, 145 \mathrm{gL}^{-1}$ (15, 65 to 194$)$; MCV, $94.4 \mathrm{fL}$ (5.1, 76.7 to 114.4); MCHC, $342 \mathrm{gL}^{-1}$ (11, 311 to 378$)$; RDW, $12.8 \%(0.8,10.4$ to 16.5$)$; D-dimer, $155 \mu \mathrm{g} \mathrm{L}^{-1}(129,18$ to 1522$)$; CA19-9, 
Table 1 Clinical characteristics between different COP-MPV groups

\begin{tabular}{|c|c|c|c|c|}
\hline Variables & $\begin{array}{l}\text { COP-MPV }=0 n \\
(\%)\end{array}$ & $\begin{array}{l}\text { COP-MPV }=1 n \\
(\%)\end{array}$ & $\begin{array}{l}\text { COP-MPV }=2 n \\
(\%)\end{array}$ & $P$ value \\
\hline Age (year) & & & & 0.299 \\
\hline$<60$ & 35 (41.2) & $160(50.6)$ & $32(47.8)$ & \\
\hline$\geq 60$ & $50(58.8)$ & $156(49.4)$ & $35(52.2)$ & \\
\hline Sex & & & & 0.004 \\
\hline Female & $20(23.5)$ & $50(15.8)$ & $22(32.8)$ & \\
\hline Male & $65(76.5)$ & $266(84.2)$ & $45(67.2)$ & \\
\hline Smoking & & & & 0.034 \\
\hline Ever & $57(67.1)$ & $163(51.6)$ & $39(58.2)$ & \\
\hline Never & $28(32.9)$ & $153(48.4)$ & $28(41.8)$ & \\
\hline Drinking & & & & 0.157 \\
\hline Yes & $36(42.4)$ & $114(36.1)$ & $32(47.8)$ & \\
\hline No & 49 (57.6) & $202(63.9)$ & $35(52.2)$ & \\
\hline Tumor location & & & & $<0.001$ \\
\hline Upper & $16(18.8)$ & $187(59.2)$ & $13(19.4)$ & \\
\hline Middle + lower & $69(81.2)$ & $129(40.8)$ & $54(80.6)$ & \\
\hline Differentiation & & & & 0.916 \\
\hline High & $20(23.5)$ & $84(26.6)$ & $17(25.4)$ & \\
\hline Moderate & $41(48.2)$ & 157 (49.7) & $32(47.8)$ & \\
\hline Poor & $24(28.2)$ & 75 (23.7) & $18(26.9)$ & \\
\hline $\begin{array}{l}\text { Maximum tumor diameter } \\
\quad(\mathrm{cm})\end{array}$ & & & & 0.930 \\
\hline$\geq 7.0$ & $18(21.2)$ & $73(23.1)$ & $15(22.4)$ & \\
\hline$<7.0$ & $67(78.8)$ & $243(76.9)$ & $52(77.6)$ & \\
\hline$N$ metastasis & & & & 0.508 \\
\hline Yes & $37(43.5)$ & $160(50.6)$ & $33(49.3)$ & \\
\hline No & $48(56.5)$ & $156(49.4)$ & $34(50.7)$ & \\
\hline TNM stage & & & & 0.096 \\
\hline I & $14(16.5)$ & $28(8.9)$ & $4(6.0)$ & \\
\hline II & $39(45.9)$ & $133(42.1)$ & $27(40.3)$ & \\
\hline III & $32(37.6)$ & $155(49.1)$ & $36(53.7)$ & \\
\hline Adjuvant radio/chemotherapy & & & & 0.484 \\
\hline Yes & $42(49.4)$ & $160(50.6)$ & $39(58.2)$ & \\
\hline No & $43(50.6)$ & $156(49.4)$ & $28(41.8)$ & \\
\hline Survival period (m) & $59.7 \pm 30.2$ & $48.7 \pm 33.3$ & $37.9 \pm 28.1$ & $<0.001$ \\
\hline
\end{tabular}

Table 2 Laboratory characteristics between different COP-MPV groups

\begin{tabular}{lcccc}
\hline Variables & COP-MPV $=0(n=75)$ & COP-MPV $=1(n=316)$ & COP-MPV $=2(n=67)$ & $P$ value \\
\hline $\mathrm{Hb}\left(\mathrm{gL}^{-1}\right)$ & $144.0 \pm 16.3$ & $145.2 \pm 14.7$ & $144.1 \pm 14.7$ & 0.728 \\
$\mathrm{MCV}(\mathrm{fL})$ & $94.3 \pm 5.2$ & $94.6 \pm 5.2$ & $93.3 \pm 4.6$ & 0.149 \\
$\mathrm{MCHC}\left(\mathrm{gL}^{-1}\right)$ & $343.1 \pm 10.1$ & $342.8 \pm 11.3$ & $339.4 \pm 11.5$ & 0.064 \\
RDW $(\%)$ & $12.7 \pm 0.8$ & $12.8 \pm 0.7$ & $12.9 \pm 0.7$ & 0.203 \\
MPV $(\mathrm{fL})$ & $9.8 \pm 0.6$ & $10.6 \pm 1.1$ & $11.3 \pm 0.5$ & $<0.001$ \\
PLT $\left(\times 10^{9} \mathrm{~L}^{-1}\right)$ & $174.6 \pm 28.2$ & $221.9 \pm 70.3$ & $254.4 \pm 32.9$ & $<0.001$ \\
D-dimer $\left(\mu \mathrm{g} \mathrm{L}^{-1}\right)$ & $186.3 \pm 201.4$ & $142.0 \pm 99.1$ & $175.9 \pm 129.6$ & 0.007 \\
CA19-9 $\left(\mathrm{U} \mathrm{mL}^{-1}\right)$ & $10.7 \pm 6.9$ & $12.2 \pm 16.2$ & $10.2 \pm 6.2$ & 0.916 \\
NLR & $1.9 \pm 1.0$ & $2.0 \pm 1.0$ & $1.9 \pm 1.4$ & 0.517 \\
PLR & $97.0 \pm 30.0$ & $111.7 \pm 43.4$ & $116.3 \pm 32.4$ & 0.004 \\
\hline
\end{tabular}


11.63 $\mathrm{U} \mathrm{mL}^{-1}$ (13.83, 0.35 to 145.30$)$; NLR, $1.98(1.02,0.53$ to 11.00); and PLR, 109.66 (40.20, 32.79 to 418.52$)$.

The relationship between COP-MPV and clinical characteristics of patients with ESCC was shown in Table 1.
Most indices had no significant differences among three groups except for sex $(P=0.004)$, smoking history $(P=0.034)$, tumor location $(P<0.001)$, and survival period $(P<0.001)$.

Table 3 Univariate analyses of overall survival and disease-free survival for all ESCC patients

\begin{tabular}{|c|c|c|c|c|}
\hline Variables & $P$ value & OS HR $(95 \% \mathrm{CI})$ & $P$ value & DFS HR $(95 \% \mathrm{CI})$ \\
\hline Age $(\geq 60$ vs $<60)$ & 0.001 & $\begin{array}{l}1.537 \\
\text { (1.206 to } 1.959)\end{array}$ & 0.002 & $\begin{array}{l}1.459 \\
(1.145 \text { to } 1.860)\end{array}$ \\
\hline Sex (male vs female) & 0.591 & $\begin{array}{l}1.088 \\
0.800 \text { to } 1.479\end{array}$ & 0.496 & $\begin{array}{l}1.113 \\
0.818 \text { to } 1.513\end{array}$ \\
\hline Tumor location (upper vs middle + lower) & 0.444 & $\begin{array}{l}1.143 \\
(0.811 \text { to } 1.611)\end{array}$ & 0.388 & $\begin{array}{l}1.163 \\
(0.825 \text { to } 1.639)\end{array}$ \\
\hline Differentiation (high, moderate, and poor) & 0.910 & $\begin{array}{l}1.019 \\
(0.738 \text { to } 1.407)\end{array}$ & 0.952 & $\begin{array}{l}1.010 \\
(0.732 \text { to } 1.395)\end{array}$ \\
\hline$N$ metastasis (presence vs absence) & $<0.001$ & $\begin{array}{l}2.134 \\
\text { (1.671 to } 2.726)\end{array}$ & $<0.001$ & $\begin{array}{l}2.116 \\
\text { (1.657 to } 2.702)\end{array}$ \\
\hline TNM stage (I + II vs III) & $<0.001$ & $\begin{array}{l}0.434 \\
(0.340 \text { to } 0.554)\end{array}$ & $<0.001$ & $\begin{array}{l}0.433 \\
(0.339 \text { to } 0.553)\end{array}$ \\
\hline Adjuvant radio/chemotherapy (yes vs no) & $<0.001$ & $\begin{array}{l}1.749 \\
\text { (1.370 to } 2.234)\end{array}$ & $<0.001$ & $\begin{array}{l}1.846 \\
\text { (1.445 to } 2.358)\end{array}$ \\
\hline Smoking (ever vs never) & 0.033 & $\begin{array}{l}1.297 \\
\text { (1.021 to } 1.647)\end{array}$ & 0.025 & $\begin{array}{l}1.313 \\
\text { (1.034 to } 1.667)\end{array}$ \\
\hline Drinking (yes vs no) & 0.576 & $\begin{array}{l}1.073 \\
(0.839 \text { to } 1.372)\end{array}$ & 0.601 & $\begin{array}{l}1.068 \\
(0.835 \text { to } 1.366)\end{array}$ \\
\hline Maximum tumor diameter $(\geq 7.0 \mathrm{vs}<7.0 \mathrm{~cm})$ & 0.001 & $\begin{array}{l}1.580 \\
(1.206 \text { to } 2.070)\end{array}$ & 0.001 & $\begin{array}{l}1.599 \\
(1.220 \text { to } 2.095)\end{array}$ \\
\hline $\mathrm{Hb}\left(\geq 135 \mathrm{vs}<135 \mathrm{gL}^{-1}\right)$ & 0.228 & $\begin{array}{l}0.847 \\
(0.647 \text { to } 1.109)\end{array}$ & 0.251 & $\begin{array}{l}0.854 \\
(0.652 \text { to } 1.118)\end{array}$ \\
\hline $\operatorname{MCV}(\geq 98.7$ vs $<98.7 \mathrm{fL})$ & 0.070 & $\begin{array}{l}1.329 \\
(0.977 \text { to } 1.808)\end{array}$ & 0.071 & $\begin{array}{l}1.327 \\
\text { (0.976 to } 1.806)\end{array}$ \\
\hline $\operatorname{MCHC}\left(\geq 344\right.$ vs $\left.<344 \mathrm{gL}^{-1}\right)$ & 0.755 & $\begin{array}{l}1.039 \\
(0.817 \text { to } 1.321)\end{array}$ & 0.660 & $\begin{array}{l}1.055 \\
(0.830 \text { to } 1.342)\end{array}$ \\
\hline RDW $(\geq 12.2$ vs $<12.2 \%)$ & 0.020 & $\begin{array}{l}1.505 \\
\text { (1.068 to } 2.122)\end{array}$ & 0.027 & $\begin{array}{l}1.474 \\
\text { (1.046 to } 2.077)\end{array}$ \\
\hline MPV $(\geq 10.6$ vs $<10.6$ fL) & 0.013 & $\begin{array}{l}1.354 \\
(1.066 \text { to } 1.720)\end{array}$ & 0.015 & $\begin{array}{l}1.347 \\
(1.060 \text { to } 1.710)\end{array}$ \\
\hline $\operatorname{PLT}\left(\geq 212\right.$ vs $\left.<212 \times 10^{9} \mathrm{~L}^{-1}\right)$ & 0.019 & $\begin{array}{l}1.332 \\
\text { (1.048 to } 1.692)\end{array}$ & 0.003 & $\begin{array}{l}1.431 \\
(1.127 \text { to } 1.819)\end{array}$ \\
\hline D-dimer $\left(\geq 207\right.$ vs $<207 \mu \mathrm{g} \mathrm{L}^{-1}$ ) & 0.164 & $\begin{array}{l}1.215 \\
(0.924 \text { to } 1.597)\end{array}$ & 0.231 & $\begin{array}{l}1.182 \\
(0.899 \text { to } 1.554)\end{array}$ \\
\hline CA19-9 ( $\geq 4.79$ vs $\left.<4.79 \mathrm{U} \mathrm{mL}^{-1}\right)$ & 0.005 & $\begin{array}{l}1.561 \\
\text { (1.148 to } 2.123)\end{array}$ & 0.005 & $\begin{array}{l}1.559 \\
(1.147 \text { to } 2.120)\end{array}$ \\
\hline $\operatorname{NLR}(\geq 2.50$ vs $<2.50)$ & 0.019 & $\begin{array}{l}1.417 \\
\text { (1.058 to } 1.899)\end{array}$ & 0.024 & $\begin{array}{l}1.400 \\
(1.045 \text { to } 1.875)\end{array}$ \\
\hline $\operatorname{PLR}(\geq 117.07$ vs $<117.07)$ & 0.047 & $\begin{array}{l}1.288 \\
\text { (1.003 to } 1.653)\end{array}$ & 0.039 & $\begin{array}{l}1.301 \\
(1.014 \text { to } 1.670)\end{array}$ \\
\hline COP-MPV $(0,1$, and 2$)$ & $<0.001$ & $\begin{array}{l}0.394(0-2) \\
(0.254 \text { to } 0.611) \\
0.691(1-2) \\
(0.504 \text { to } 0.948)\end{array}$ & $<0.001$ & $\begin{array}{l}0.350(0-2) \\
(0.226 \text { to } 0.543) \\
0.630(1-2) \\
(0.459 \text { to } 0.863)\end{array}$ \\
\hline
\end{tabular}


Table 2 showed the distribution of multiple laboratory variables in three groups divided by COP-MPV. MPV $(P<0.001)$, PLT $(P<0.001)$, D-dimer $(P=0.007)$, and PLR $(P=0.004)$ showed significant differences.

We next separated the cohort into different groups by cutoff values of clinicolaboratory variables. Survival analyses of OS and DFS in relation to every selected variable were performed. In univariate analyses, age $(\geq 60 /<60)$ (hazard ratio (HR) $1.537,95 \%$ confidence interval (CI) 1.206 to 1.959 , $P=0.001$ ), lymph node metastasis (presence/absence) (HR $2.134,95 \%$ CI 1.671 to $2.726, P<0.001$ ), TNM stage (I + II/III) (HR 0.434, $95 \%$ CI 0.340 to $0.554, P<0.001$ ), adjuvant therapy (yes/no) (HR 1.749, $95 \%$ CI 1.370 to 1.224 , $P<0.001$ ), smoking (ever/never) (HR 1.297, $95 \%$ CI 1.021 to $1.647, P=0.033)$, maximum tumor diameter $(\geq 7.0 /$ $<7.0 \mathrm{~cm}$ ) (HR 1.580, $95 \%$ CI 1.206 to $2.070, P=0.001$ ), RDW ( $\geq 12.2 /<12.2 \%$ ) (HR 1.505, $95 \%$ CI 1.068 to 2.122 , $P=0.020), \mathrm{MPV}(\geq 10.6 /<10.6 \mathrm{fL})(\mathrm{HR} 1.354,95 \%$ CI 1.066 to $1.720, P=0.013)$, PLT $\left(\geq 212 /<212 \times 10^{9} \mathrm{~L}^{-1}\right)(\mathrm{HR} 1.332$, $95 \%$ CI 1.048 to $1.692, P=0.019)$, CA19-9 $(\geq 4.79 /$ $\left.<4.79 \mathrm{U} \mathrm{mL}^{-1}\right)(\mathrm{HR} 1.561,95 \% \mathrm{CI} 1.148$ to 2.123 , $P=0.005)$, NLR $(\geq 2.50 /<2.50)$ (HR $1.417,95 \%$ CI 1.058 to $1.899, P=0.019)$, PLR $(\geq 117.07 /<117.07)(\mathrm{HR} 1.288,95 \%$ CI 1.003 to $1.653, P=0.047$ ), and COP-MPV (HR 0.394,
$95 \%$ CI 0.254 to $0.611, P<0.001)$ were associated with OS (Table 3). Similar results were revealed in the relationships of these factors with DFS (Table 3). Multivariate analyses demonstrated that age (HR 1.595, $95 \%$ CI 1.236 to 2.059, $P<0.001$ ), lymph node metastasis (HR 1.869, $95 \% \mathrm{CI}$ 1.421 to $2.458, P<0.001$ ), adjuvant therapy (HR 1.327, $95 \%$ CI 1.006 to $1.751, P=0.045)$, maximum tumor diameter (HR 1.365, $95 \%$ CI 1.019 to $1.828, P=0.037$ ), CA19-9 (HR $1.740,95 \%$ CI 1.270 to $2.385, P<0.001)$, and COP-MPV (HR $0.378,95 \%$ CI 1.270 to $2.385, P<0.001$ ) were independent prognostic factors of ESCC patients (Table 4).

Moreover, we examined the prognostic value of COPMPV in subgroups of early and advanced stages of ESCC patients. Hazard ratios of OS and DFS were found significantly different among three COP-MPV groups in both early (OS, $P=0.025$; DFS, $P=0.018$ ) and advanced stages (OS, $P=0.029$; DFS, $P=0.002$ ). However, PLT or MPV alone did not show that predictive function as they combined (MPV for early stage, $P=0.334$ (Fig. 2a); MPV for advanced stage, $P=0.085$ (Fig. 2b); and PLT for advanced stage, $P=0.254$ (Fig. 3b)) (Table 5).

By Kaplan-Meier analyses, significant differences in OS and DFS among COP-MPV groups were demonstrated $(P<0.001)$, where COP-MPV $=2$ group tended to have worse
Table 4 Multivariate analyses of overall survival and disease-free survival for all ESCC patients

\begin{tabular}{|c|c|c|c|c|}
\hline Variables & $P$ value & OS HR $(95 \% \mathrm{CI})$ & $P$ value & DFS HR $(95 \% \mathrm{CI})$ \\
\hline Age $(\geq 60$ vs $<60)$ & $<0.001$ & $\begin{array}{l}1.595 \\
(1.236 \text { to } 2.059)\end{array}$ & 0.002 & $\begin{array}{l}1.498 \\
(1.162 \text { to } 1.930)\end{array}$ \\
\hline$N$ metastasis (yes vs no) & $<0.001$ & $\begin{array}{l}1.869 \\
\text { (1.421 to } 2.458)\end{array}$ & $<0.001$ & $\begin{array}{l}1.816 \\
\text { (1.381 to } 2.389)\end{array}$ \\
\hline Adjuvant radio/chemotherapy (yes vs no) & 0.045 & $\begin{array}{l}1.327 \\
(1.006 \text { to } 1.751)\end{array}$ & 0.015 & $\begin{array}{l}1.411 \\
(1.070 \text { to } 1.860)\end{array}$ \\
\hline Smoking (ever vs never) & 0.622 & $\begin{array}{l}1.066 \\
(0.827 \text { to } 1.374)\end{array}$ & 0.611 & $\begin{array}{l}1.068 \\
(0.830 \text { to } 1.373)\end{array}$ \\
\hline Maximum tumor diameter $(\geq 7.0 \mathrm{vs}<7.0 \mathrm{~cm})$ & 0.037 & $\begin{array}{l}1.365 \\
\text { (1.019 to } 1.828)\end{array}$ & 0.046 & $\begin{array}{l}1.348 \\
\text { (1.006 to } 1.806)\end{array}$ \\
\hline $\operatorname{MCV}(\geq 98.7$ vs $<98.7 \mathrm{fL})$ & 0.095 & $\begin{array}{l}1.310 \\
(0.954 \text { to } 1.798)\end{array}$ & 0.092 & $\begin{array}{l}1.311 \\
(0.957 \text { to } 1.796)\end{array}$ \\
\hline RDW ( $\geq 12.2$ vs $<12.2 \%)$ & 0.095 & $\begin{array}{l}1.356 \\
(0.948 \text { to } 1.940)\end{array}$ & 0.101 & $\begin{array}{l}1.349 \\
(0.943 \text { to } 1.929)\end{array}$ \\
\hline CA19-9 $\left(\geq 4.79\right.$ vs $\left.<4.79 \mathrm{U} \mathrm{mL}^{-1}\right)$ & 0.001 & $\begin{array}{l}1.740 \\
(1.270 \text { to } 2.385)\end{array}$ & 0.001 & $\begin{array}{l}1.722 \\
(1.258 \text { to } 2.358)\end{array}$ \\
\hline NLR & 0.124 & $\begin{array}{l}1.283 \\
(0.934 \text { to } 1.763)\end{array}$ & 0.180 & $\begin{array}{l}1.245 \\
(0.904 \text { to } 1.714)\end{array}$ \\
\hline PLR & 0.187 & $\begin{array}{l}1.203 \\
(0.915 \text { to } 1.582)\end{array}$ & 0.172 & $\begin{array}{l}1.210 \\
(0.920 \text { to } 1.591)\end{array}$ \\
\hline COP-MPV $(0,1$, and 2$)$ & $<0.001$ & $\begin{array}{l}0.378(0-2) \\
(0.241 \text { to } 0.593) \\
0.677(1-2) \\
(0.490 \text { to } 0.535)\end{array}$ & $<0.001$ & $\begin{array}{l}0.341(0-2) \\
(0.218 \text { to } 0.534) \\
0.620(1-2) \\
(0.449 \text { to } 0.856)\end{array}$ \\
\hline
\end{tabular}


Table 5 Univariate analyses of overall survival and disease-free survival for early stage (TNM I and II) and locally advanced (TNM III) stage patients

\begin{tabular}{|c|c|c|c|c|c|}
\hline Variables & $\begin{array}{l}\text { TNM } \\
\text { stage }\end{array}$ & $P$ value & OS HR $(95 \% \mathrm{CI})$ & $P$ value & DFS HR $(95 \% \mathrm{CI})$ \\
\hline \multirow[t]{2}{*}{ MPV $(\geq 10.6$ vs $<10.6 \mathrm{fL})$} & I and II & 0.334 & $\begin{array}{l}1.203 \\
(0.827 \text { to } 1.752)\end{array}$ & 0.349 & $\begin{array}{l}1.196 \\
(0.822 \text { to } 1.742)\end{array}$ \\
\hline & III & 0.085 & $\begin{array}{l}1.317 \\
(0.963 \text { to } 1.801)\end{array}$ & 0.098 & $\begin{array}{l}1.303 \\
(0.952 \text { to } 1.782)\end{array}$ \\
\hline \multirow[t]{2}{*}{$\operatorname{PLT}\left(\geq 212\right.$ vs $\left.<212 \times 10^{9} \mathrm{~L}^{-1}\right)$} & I and II & 0.024 & $\begin{array}{l}1.545 \\
\text { (1.059 to } 2.254)\end{array}$ & 0.014 & $\begin{array}{l}1.602 \\
\text { (1.099 to } 2.337)\end{array}$ \\
\hline & III & 0.254 & $\begin{array}{l}1.198 \\
(0.878 \text { to } 1.634)\end{array}$ & 0.050 & $\begin{array}{l}1.365 \\
\text { (1.000 to } 1.862)\end{array}$ \\
\hline \multirow[t]{2}{*}{ COP-MPV $(0,1$, and 2$)$} & I and II & 0.025 & $\begin{array}{l}0.400(0-2) \\
(0.204 \text { to } 0.786) \\
0.732(1-2) \\
(0.438 \text { to } 1.225)\end{array}$ & 0.018 & $\begin{array}{l}0.385(0-2) \\
(0.196 \text { to } 0.756) \\
0.727(1-2) \\
(0.435 \text { to } 1.215)\end{array}$ \\
\hline & III & 0.029 & $\begin{array}{l}0.465(0-2) \\
(0.259 \text { to } 0.833) \\
0.671(1-2) \\
(0.450 \text { to } 1.001)\end{array}$ & 0.002 & $\begin{array}{l}0.371(0-2) \\
(0.207 \text { to } 0.665) \\
0.554(1-2) \\
(0.371 \text { to } 0.829)\end{array}$ \\
\hline
\end{tabular}

prognosis than other two groups (Fig. 1a, b). The 5-year survival rates for groups 0,1 , and 2 were $64.3,43.1$, and $28.0 \%$, respectively. We illustrated the effect of one known prognostic factor (lymph node metastasis) to postoperative survival for
Fig. 1 Kaplan-Meier curves of overall survival (a) and diseasefree survival (b) for 468 ESCC patients by COP-MPV category. $P$ values were determined by the log-rank test. Relationship between known prognostic factors (lymph node metastasis status) and OS/DFS were shown in (c) and (d) for comparison
A

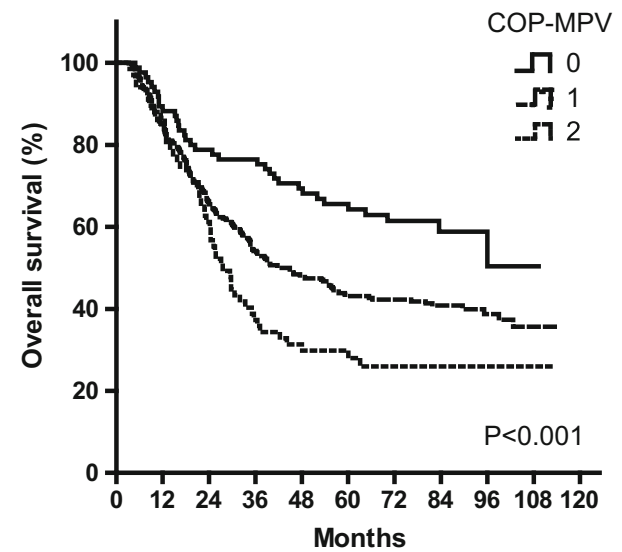

C

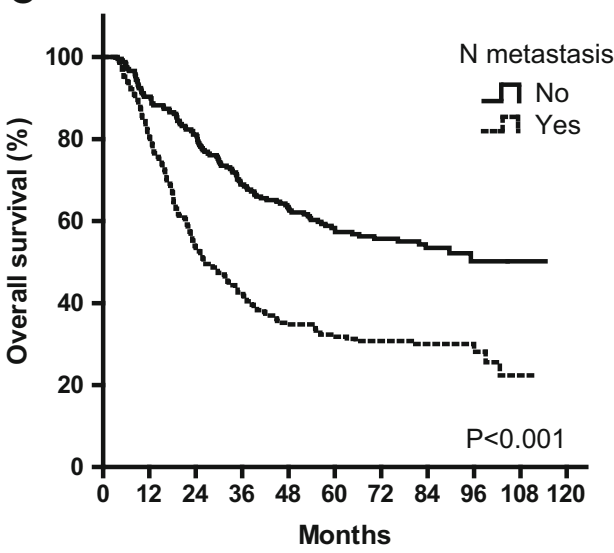

B

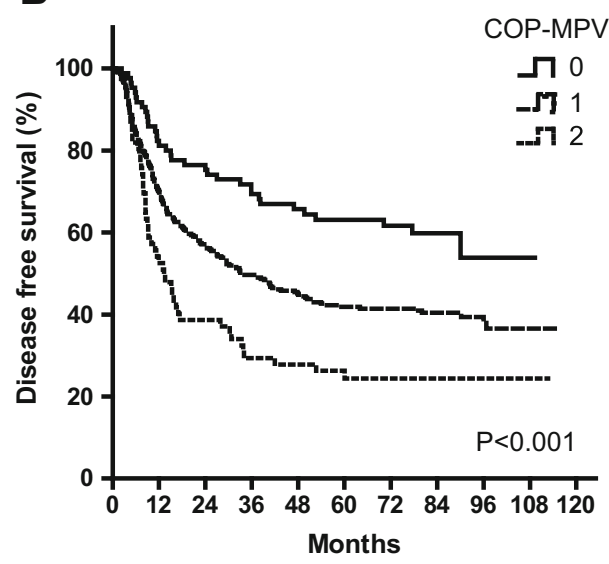

D

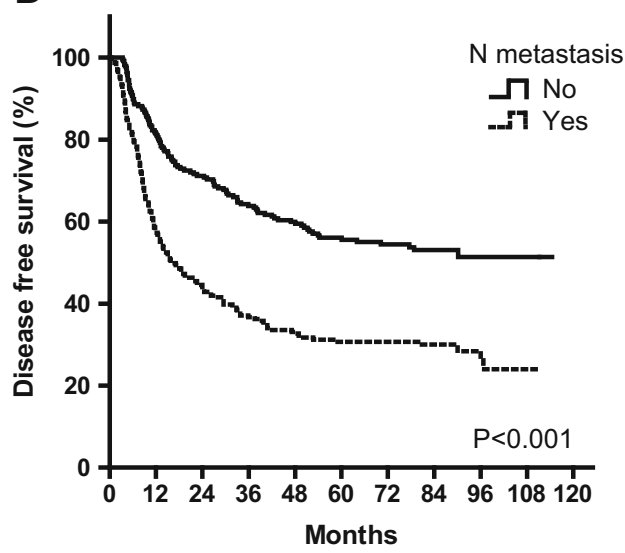



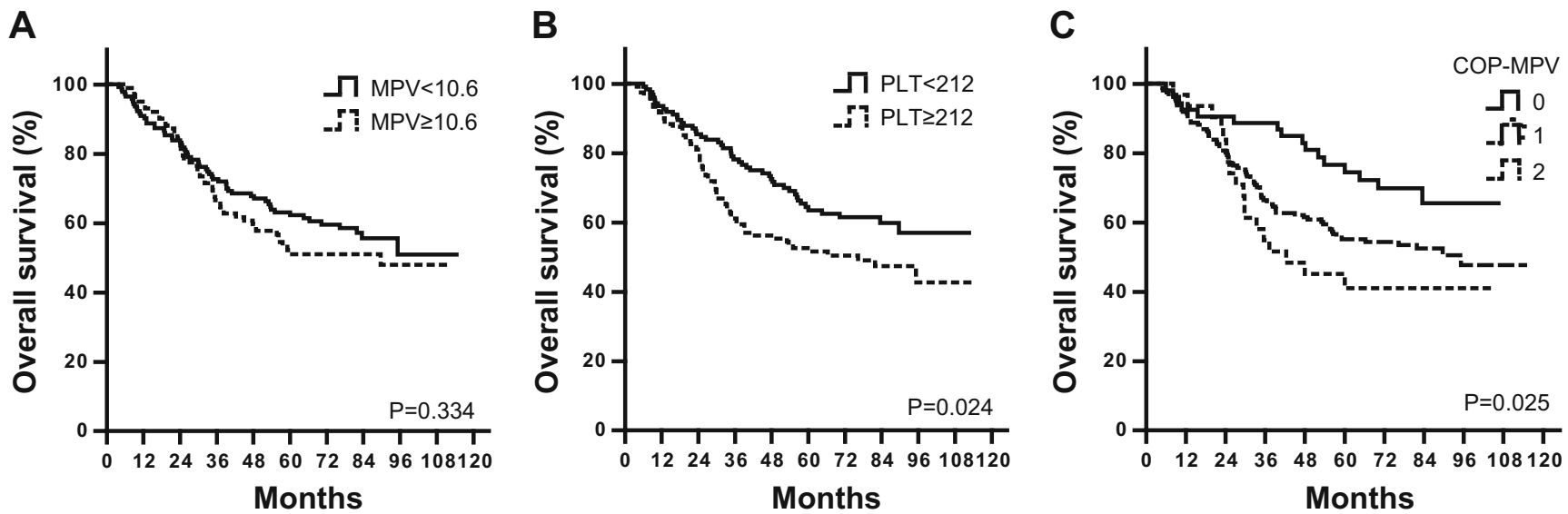

Fig. 2 Kaplan-Meier curves of overall survival for stages I and II patients $(n=245)$ by a MPV, b PLT, and c COP-MPV categories. $P$ values were determined by the log-rank test. COP-MPV category showed best predictive power

comparison (Fig. 1c, d). In subgroup analyses, COP-MPV showed its predictive value in both early (TNM stages I and II) and advanced stages (TNM stage III) of ESCC patients. In the early stage subgroup, patients with COP-MPV $=2$ were prone to live shorter compared to 0 or 1 groups $(P=0.025)$ (Fig. 2c), where 5-year survival rates for groups 0,1 , and 2 were $74.5,55.2$, and $44.1 \%$, respectively. Similar results were revealed in the advanced stage group $(P=0.029$; Fig. $3 \mathrm{c})$, where 5 -year survival rates for groups 0,1 , and 2 were 46.9 , 31.3 , and $16.7 \%$, respectively.

\section{Discussion}

Platelet activation has been previously reported as a common phenomenon in cardiovascular diseases such as acute ischemic stroke, myocardial infarction, and renal artery stenosis $[22,23]$. Recently, more attention has been paid on the clinical significance of this process in several malignancies [24, 25].
The two main aspects to assess the platelet activation status are PLT and MPV [12]. Researchers noticed that many cancers were related to elevation of platelet count in peripheral blood (or thrombocytosis), which were considered to be caused by upstream cytokine stimulation [26] or oncogenesis itself [27, 28]. Emerging evidence suggested that high PLT or PLR indicated poor postoperative survival in several solid tumors [13, 29-31]. On the other hand, MPV also showed promising utility to stratify benign and malignant diseases, although high MPV indicated that malignant disease/poor survival remained controversial [32-34]. Therefore, it is reasonable to combine PLT and MPV as a scoring system (COP-MPV) for platelet activation to evaluate the prognosis of cancer patients.

In this study, we evaluated the association between multiple clinicopathological variables and OS/DFS and found that COP-MPV had the best discriminatory ability as lymph node metastasis status (Table 4 and Fig. 1). NLR and PLR were also significant prognostic factors in univariate analysis but not independent in multivariate Cox regression. This was possibly because their stratifying ability was absorbed by the COP-
A

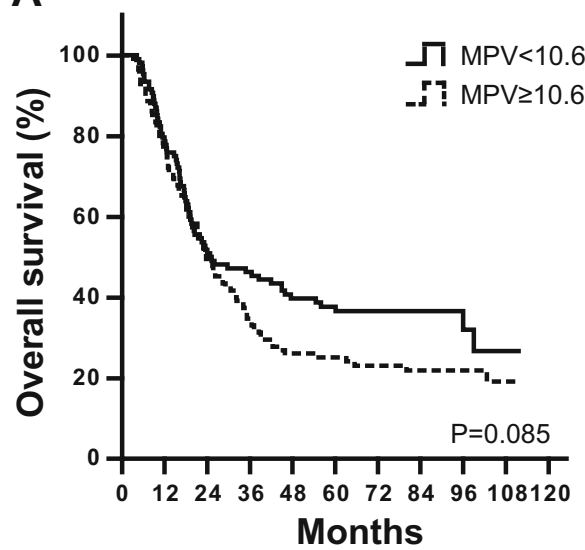

B

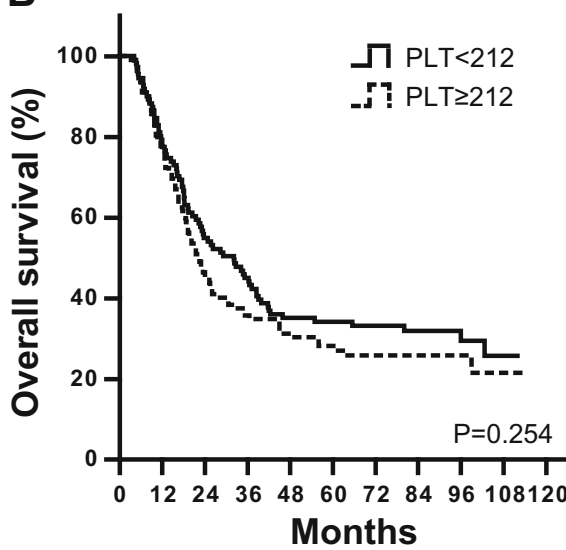

C

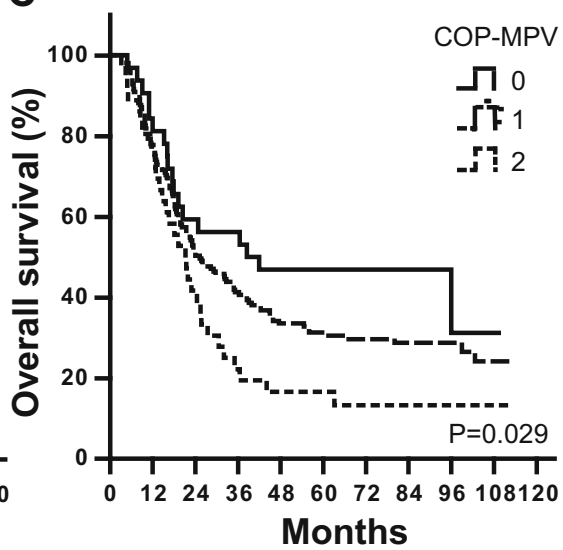

Fig. 3 Kaplan-Meier curves of overall survival for stage III patients $(n=223)$ by a MPV, $\mathbf{b}$ PLT, and $\mathbf{c}$ COP-MPV categories. $P$ values were determined by the log-rank test. COP-MPV category showed best predictive power 
MPV score. Moreover, we revealed that COP-MPV had a predictive utility in both early and advanced subgroups of ESCC patients (Table 5 and Figs. 2c and 3c). In fact, PLT was more favorable to stratify the survival period for early stage ESCC patients $(P=0.024$; Fig. $2 b)$, while MPV for advanced stage was though not significant $(P=0.085$; Fig. $3 b)$. The combination of PLT and MPV was effective in both subgroups as it seemed gathering the advantages of the two indices measuring platelet activation.

The history for investigating MPV as a tumor prognostic marker was not long, but evidence was increasing [32, 35-37]. For instance, Aksoy and colleagues demonstrated that solid tumors with bone marrow metastasis were more likely to have low MPV [32]; a Korean group revealed that high MPV stratified liver cancer compared to normal controls [35]. MPV level was found significantly higher in advanced endometrial cancer compared to early stage patients or healthy controls [36]. Nevertheless, the relationship of MPV value and overall survival was not consistent in different studies. In non-smallcell lung cancer (NSCLC), two Japanese groups announced that low MPV level was associated with unfavorable survival $[34,37]$. Their explanation was that the product for PLT $\times$ MPV was relatively constant. On the other hand, massive researches proved that high PLT level predicted short postoperative survival [13-16]. Thus, it was reasonable that low MPV level (=high PLT level) resembles active inflammation status which could cause poor prognosis. However, evidence for relationship of high MPV and advanced stage cancer (or unfavorable disease-like thrombotic state) is also emerging, such as in colon cancer [38], blood tumor [39], renal cancer [40], hepatocellular carcinoma [18, 35], gastric cancer [20], and endometrial cancer [36]. The underlying mechanism was also straightforward - the process of platelet activation, stimulated by inflammatory factor such as interleukin-6, was likely to produce platelet with both characteristics, massive and giant, not only one. Therefore, we could expect that both platelet count and volume would be increasing in an unfavorable disease compared to a more benign one. Our study in ESCC supported the latter.

An apparent obstacle for applying these direct blood indices (such as PLT or MPV) is to determine the cutoff values. In our study, $41(8.8 \%)$ patients were with thrombocytosis $\left(\mathrm{PLT}>300 \times 10^{9} \mathrm{~L}^{-1}\right)$ and $9(1.9 \%)$ patients were with abnormal high MPV (>13.0 fL), which had hardly statistically significance on overall survival. However, previous studies on prognostic potential of these markers revealed that poor survival was more likely to be related to elevated tendency, not necessarily to abnormal value (i.e., thrombocytosis or high MPV) $[29,41]$. Actually, indirect indices like PLR or NLR were widely used partly because the cutoff values for these indirect indices were not unique. Therefore, our cutoff values for PLT and MPV based on ROC curves, though not the normal-abnormal dividing line, were plausible.
In conclusion, our study proved that combined blood biomarker COP-MPV has prognostic value in 468 ESCC patients. Besides, the predictive ability is effective in both early (TNM I and II) and advanced (TNM III) subgroup patients. To the best of our knowledge, this is the first time to combine the two platelet activation markers together to evaluate their prognostic potential, which would help clinicians to predict the survival of ESCC patients.

Acknowledgments We thank Zhou Fang for the careful work for information collection of ESCC patients. We are also grateful to Xiong Meihua and all the staff in the Lab and Tumor Bank of the Department of Thoracic Surgery for their support during the study.

Funding This study was supported by the National Natural Science Foundation of China (81372219, 81301851, and U1302223) and Beijing Natural Science Foundation (7141011).

\section{Conflicts of interest None}

Open Access This article is distributed under the terms of the Creative Commons Attribution 4.0 International License (http:// creativecommons.org/licenses/by/4.0/), which permits unrestricted use, distribution, and reproduction in any medium, provided you give appropriate credit to the original author(s) and the source, provide a link to the Creative Commons license, and indicate if changes were made.

\section{References}

1. Ferlay J, Soerjomataram I, Dikshit R, Eser S, Mathers C, Rebelo M, et al. Cancer incidence and mortality worldwide: sources, methods and major patterns in GLOBOCAN. Int J Cancer. 2012;136(5): E359-86.

2. Zhang SW, Zhang M, Li GL, Wei WQ, Meng FS, Liu ZC, et al. An analysis of incidence and mortality of oesophageal cancer in China, 2003-2007. China Cancer. 2012;21:241-7.

3. Mao YS, He J, Cheng GY. Current status of surgical management of esophageal cancer in China and the future strategy. Zhonghua Zhong Liu Za Zhi. 2010;32:401-4.

4. Enzinger PC, Mayer RJ. Esophageal cancer. N Engl J Med. 2003;349:2241-52.

5. Guo Y, Chen Z, Zhang L, Zhou F, Shi S, Feng X, et al. Distinctive microRNA profiles relating to patient survival in esophageal squamous cell carcinoma. Cancer Res. 2008;68:26-33.

6. Harada K, Ida S, Baba Y, Ishimoto T, Kosumi K, Tokunaga R, et al. Prognostic and clinical impact of sarcopenia in esophageal squamous cell carcinoma. Dis Esophagus. 2015. doi:10.1111/dote. 12381.

7. Zheng YZ, Wen J, Cao X, Yang H, Luo KJ, Liu QW, et al. Decreased mRNA expression of transcription factor forkhead box F2 is an indicator of poor prognosis in patients with resected esophageal squamous cell carcinoma. Mol Clin Oncol. 2015;3(3):713-9.

8. Tong M, Chan KW, Bao JY, Wong KY, Chen JN, Kwan PS, et al. Rab25 is a tumor suppressor gene with antiangiogenic and antiinvasive activities in esophageal squamous cell carcinoma. Cancer Res. 2012;72:6024-35.

9. Lip GY, Chin BS, Blann AD. Cancer and the prothrombotic state. Lancet Oncol. 2002;3(1):27-34. 
10. Nash GF, Turner LF, Scully MF, Kakkar AK. Platelets and cancer. Lancet Oncol. 2002;3(7):425-30.

11. Gay LJ, Felding-Habermann B. Contribution of platelets to tumour metastasis. Nat Rev Cancer. 2011;11:123-34.

12. Kamath S, Blann AD, Lip GY. Platelet activation: assessment and quantification. Eur Heart J. 2001;22(17):1561-71.

13. Stone RL, Nick AM, McNeish IA, Balkwill F, Han HD, BottsfordMiller J, et al. Paraneoplastic thrombocytosis in ovarian cancer. N Engl J Med. 2012;366(7):610-8.

14. Gorelick C, Andikyan V, Mack M, Lee YC, Abulafia O. Prognostic significance of preoperative thrombocytosis in patients with endometrial carcinoma in an inner-city population. Int J Gynecol Cancer. 2009;19:1384-9.

15. Ishizuka M, Oyama Y, Abe A, Kubota K. Combination of platelet count and neutrophil to lymphocyte ratio is a useful predictor of postoperative survival in patients undergoing surgery for gastric cancer. J Surg Oncol. 2014;110:935-41.

16. Josa V, Krzystanek M, Eklund AC, Salamon F, Zarand A, Szallasi $\mathrm{Z}$, et al. Relationship of postoperative thrombocytosis and survival of patients with colorectal cancer. Int J Surg. 2015;18:1-6.

17. Kai H, Kitadai Y, Kodama M, Cho S, Kuroda T, Ito M, et al. Involvement of proinflammatory cytokines IL-1beta and IL-6 in progression of human gastric carcinoma. Anticancer Res. 2005;25:709-13.

18. Kurt M, Onal IK, Sayilir AY, Beyazıt Y, Ozta SE, Kekilli M, et al. The role of mean platelet volume in the diagnosis of hepatocellular carcinoma in patients with chronic liver disease. HepatoGastroenterology. 2012;59:1580-2.

19. Karaman K, Bostanci EB, Aksoy E, Kurt M, Celep B, Ulas M, et al. The predictive value of mean platelet volume in differential diagnosis of nonfunctional pancreatic neuroendocrine tumors from pancreatic adenocarcinomas. Eur J Intern Med. 2011;22:95-8.

20. Kilınçalp S, Ekiz F, Başar O, Ayte MR, Coban S, Yılmaz B, et al. Mean platelet volume could be possible biomarker in early diagnosis and monitoring of gastric cancer. Platelets. 2014;25(8):592-4.

21. Edge SB, Compton CC. The American Joint Committee on Cancer: the 7th edition of the AJCC cancer staging manual and the future of TNM. Ann Surg Oncol. 2010;17:1471-4.

22. Fitzgerald DJ, Roy L, Catella F, FitzGerald GA. Platelet activation in unstable coronary disease. N Engl J Med. 1986;315(16):983-9.

23. Kapoor JR. Platelet activation and atherothrombosis. N Engl J Med. 2008;358(15):1638.

24. Connolly GC, Phipps RP, Francis CW. Platelets and cancerassociated thrombosis. Semin Oncol. 2014;41(3):302-10.

25. Stegner D, Dütting S, Nieswandt B. Mechanistic explanation for platelet contribution to cancer metastasis. Thromb Res. 2014;133 Suppl 2:S149-57.

26. Sierko E, Wojtukiewicz MZ. Platelets and angiogenesis in malignancy. Semin Thromb Hemost. 2004;30(1):95-108.

27. Gunsilius E, Petzer A, Stockhammer G, Nussbaumer W, Schumacher P, Clausen J, et al. Thrombocytes are the major source for soluble vascular endothelial growth factor in peripheral blood. Oncology. 2000;58(2):169-74.

28. Khorana AA, Fine RL. Pancreatic cancer and thromboembolic disease. Lancet Oncol. 2004;5(11):655-63.

29. Li X, Chen ZH, Xing YF, Wang TT, Wu DH, Wen JY, et al. Plateletto-lymphocyte ratio acts as a prognostic factor for patients with advanced hepatocellular carcinoma. Tumour Biol. 2015;36(4):2263-9.

30. Li C, Wen TF, Yan LN, Li B, Wang WT, Yang JY, et al. Postoperative neutrophil-to-lymphocyte ratio plus platelet-tolymphocyte ratio predicts the outcomes of hepatocellular carcinoma. J Surg Res. 2015;198(1):73-9.

31. Zhang H, Zhang L, Zhu K, Shi B, Yin Y, Zhu J, et al. Prognostic significance of combination of preoperative platelet count and neutrophil-lymphocyte ratio (COP-NLR) in patients with nonsmall cell lung cancer: based on a large cohort study. PLoS One. 2015;10(5), e0126496. doi:10.1371/journal.pone.0126496.

32. Aksoy S, Kilickap S, Hayran M, Harputluoglu H, Koca E, Dede DS, et al. Platelet size has diagnostic predictive value for bone marrow metastasis in patients with solid tumors. Int $\mathrm{J}$ Lab Hematol. 2008;30(3):214-9.

33. Osada J, Rusak M, Kamocki Z, Dabrowska MI, Kedra B. Platelet activation in patients with advanced gastric cancer. Neoplasma. 2010;57(2):145-50

34. Inagaki N, Kibata K, Tamaki T, Shimizu T, Nomura S. Prognostic impact of the mean platelet volume/platelet count ratio in terms of survival in advanced non-small cell lung cancer. Lung Cancer. 2014;83(1):97-101.

35. Cho SY, Yang JJ, You E, Kim BH, Shim J, Lee HJ, et al. Mean platelet volume/platelet count ratio in hepatocellular carcinoma. Platelets. 2013;24(5):375-7.

36. Oge T, Yalcin OT, Ozalp SS, Isikci T. Platelet volume as a parameter for platelet activation in patients with endometrial cancer. J Obstet Gynaecol. 2013;33(3):301-4.

37. Kumagai S, Tokuno J, Ueda Y, Marumo S, Shoji T, Nishimura T, et al. Prognostic significance of preoperative mean platelet volume in resected non-small-cell lung cancer. Mol Clin Oncol. 2015;3(1): 197-201.

38. Li JY, Li Y, Jiang Z, Wang RT, Wang XS. Elevated mean platelet volume is associated with presence of colon cancer. Asian Pac J Cancer Prev. 2014;15(23):10501-4.

39. Kissova J, Bulikova A, Ovesna P, Bourkova L, Penka M. Increased mean platelet volume and immature platelet fraction as potential predictors of thrombotic complications in BCR/ABL-negative myeloproliferative neoplasms. Int J Hematol. 2014;100(5):429-36.

40. Gunduz S, Mutlu H, Uysal M, Coskun HS, Bozcuk H. Elucidating the correlation between treatment with tyrosine kinase inhibitors and mean platelet volume in patients with metastatic renal cell cancer. Oncol Lett. 2014;8(5):2249-52.

41. Wei XL, Wang FH, Zhang DS, Qiu MZ, Ren C, Jin Y, et al. A novel inflammation-based prognostic score in esophageal squamous cell carcinoma: the $\mathrm{C}$-reactive protein/albumin ratio. BMC Cancer. 2015; 15:350. 